\title{
Narrating in Cooperative Learning Integrated Reading and Composition (CIRC) Learning in Elementary School to Improve Reading Skills
}

\author{
Gde Artawan * \\ Department of Language Education Postgraduates, \\ Universitas Pendidikan Ganesha, Singaraja, Indonesia \\ e-mail: gde.artawan@undiksha.ac.id
}

\begin{abstract}
The current real condition in Indonesia, reading has not become a daily culture of society, especially for the students. For the students, reading is not something fun to be done even on the contrary it becomes something boring and saturating. This study aimed at examining the effect of the Cooperative Integrated Reading and Composition (CIRC) learning model assisted by a fairytale toward students' reading skills. This study was a quasi-experimental study designed in a nonequivalent post-test only control group. The population of this study was 98 students. The sample of this study was the fifth grade of Kaliuntu 3 Elementary School, with 23 students and the fifth grade of Kaliuntu 2 Elementary School with 18 students, determined by random sampling technique. Reading skill test in the form of an objective test of 25 questions was used as the instrument. The obtained data were analyzed using inferential statistical analysis (t-test). Based on the results of the t-test calculation, $t_{c o u n t}$ was greater than table (tcount $4.31>t_{\text {table }}$ 2.042) so $\mathrm{HO}$ was rejected and Ha was accepted. It means that there are significant differences in reading skills between the groups of students who are taught using Cooperative Integrated Reading and Composition (CIRC) learning models assisted by fairy tales and the groups of students who were taught using conventional learning. Based on the average value it was known that the average value of the experimental group was greater than the control group. Thus, it can be concluded that the fairytale assisted Cooperative Integrated Reading and Composition (CIRC) learning model has a positive effect on students' reading skills in elementary school students. This finding will have implications that are to improve students' reading skills at the elementary school can be done by using a CIRC learning model assisted by fairy tales.
\end{abstract}

Keywords: CIRC Learning Model; Fairy Tales; Reading Skills

\section{Introduction}

Indonesian has an important position and function in the nation and state life so it is necessary to be taught in an educational unit, not least at the basic level of education. In learning Indonesian, besides being skilled in language, students must acquire a reading skill. However, in the current real conditions, especially in Indonesia, reading has not become a daily culture of society. Learning to read is something that begins in childhood and goes through various processes (Pfost et al., 2019). For students, reading is not something fun to do even on the contrary becomes something that is considered boring and saturating. Reading difficulty remains the most significant social problem (Loberg et al., 2019). It is supported by the results of the observation in the field, namely in X Cluster Buleleng District, Buleleng Regency shows the same thing, the reading skills of the fifth-grade students are still relatively low. It is proven by the partial score of the middle test which is still below the Minimum Mastery Criteria (MMC). Also, based on the results of interviews conducted by the teacher of fifth grade in X Cluster Buleleng District, Buleleng Regency. Some problems related to the low reading skills of the fifth-grade students are caused by several factors, namely: 1) Some teachers have applied an innovative learning model but it has not run optimally; 2) There are still many students who do not listen to the teacher's explanation; 3 )

\footnotetext{
${ }^{*}$ Corresponding author.

Received 5 April 2020; Accepted 6 June 2020; Available online 20 June 2020

(C) 2020 JPI. All Rights Reserved
} 
The teacher has not fully applied and utilized the media in learning activities maximally. These problems are also found in the research conducted by (Maulida et al., 2017) where the teacher has not been maximal in using the learning model and the use of media is still minimal so it does not attract the attention of students.

Also, generally, the ability of primary students to pay attention is still limited. If they spend 15 minutes to concentrate on something, they will start to move their bodies, stand up, look back to the side, or start observing other objects. The students of Elementary School (ES) are still in childhood where they will feel bored if they learn too long (Kartika et al., 2013). Further observations also found the learning process in class on the date which indicated that the learning activities were still dominated by the teacher. In the learning process, the teachers talk and the students listen as well as record what the teachers say. Besides, this is also caused by the lack of teacher mastery toward reading theories so that teachers must be able to master reading theories before teaching them to the students. Therefore, the student involvement is very minimal and make students bored and saturated, students only wait for the instructions from their teacher during the learning process, especially in reading activities. The same problem was also found in the research conducted by (Yudasmini et al., 2015) that Indonesian language learning tended to conventional learning. Learning is dominated by lecturing and questioning as well as answering methods so it causes the passivity and lack of students' interaction in the learning process.

Oral and written language skills have a very important role in human life (Sumantri et al., 2017). In Indonesian, there are four skills interrelated with each other, including listening skills, speaking skills, reading skills, and writing skills. Reading skill becomes a priority scale that students must be mastered (Ismail et al., 2017). Reading has a very important role in daily life, through reading students will obtain various information that has never been obtained before. A very good thing to do if a teacher can motivate students to read is by letting the students read whatever they want to read for a few minutes before learning begins while still being accompanied by their teacher (Ahmadi, 2017). Reading has a role in knowing various kinds of advances in science and technology that develop increasingly (Sandiyani et al., 2016). Through reading, the advance in science and technology can be known and understood before it can be applied. Reading can be likened as a key to open a repository of knowledge and science

One solution to overcome the problem of low student' reading skills is to use an innovative learning model, by combining learning model with a specific media to stimulate children's reading skills. Cooperative learning is one of the learning models that can increase student activity (Ristanto et al., 2017). Cooperative learning is student-centered learning and teaching refers to small groups arranged heterogeneously (Motaei, 2014). By using cooperative learning model, the students will help each other or implement peer tutors, their critical thinking skills will develop and students will actively participate in the learning process (Durukan, 2011). According to (Aziz \& Hossain, 2010) cooperative learning is suitable to be applied in all disciplines. So, the learning model can help students to improve reading skills by conducting one type of cooperative learning model like Cooperative Integrated Reading and Composition (CIRC). Cooperative Integrated Reading and Composition (CIRC) learning model is one of the innovative learning models that combines reading and writing skills in a group. The Cooperative Integrated Reading and Composition (CIRC) learning model is a learning model using a group system or small team, which consists of four people heterogeneously (Setiawati et al., 2017). When learning is conducted by using the CIRC learning model, the students work together with their groups to compete with other groups in which students will generally read paragraphs in reading text alternately (Khoirunisa et al., 2017).

In the Cooperative Integrated Reading and Composition (CIRC) learning, each student is responsible for the group work. This learning model starts from elementary school to high school. This learning process educates the students to interact with the environment. The discussion activities of students will determine the success of students' understanding of all learning concepts (Yudasmini et al., 2015). Furthermore, (llham et al., 2016) explain that work success is strongly influenced by the involvement of each group member itself. 
According to (Kurniasih \& Sani, 2016) the strengths of Cooperative Integrated Reading and Composition (CIRC) learning models are: 1) The experiences and learning activities of students will always be relevant to the level of child development, 2) The chosen activities are appropriate and depart from student interests and children's needs, 3) All learning activities are more meaningful for students so that the learning outcomes of students will last longer, 4) Integrated learning can foster children's thinking skills, 5) Integrated learning presents some activities that are pragmatic (useful) related to the problems that are often encountered in the child's environment, 6) Integrated learning can foster student' learning motivation toward learning that is dynamic, optimal, and appropriate, 7) Fostering children's social interactions such as cooperation, tolerance, communication, and respect for other people's ideas, and 8) Generating motivation to learn, broaden insights, and teacher' aspirations in teaching.

Considering the effectiveness of students' absorption toward a difficult and complicated subject matter, it can be increased if it is learned by the assistance of an instructional media. According to (Djamarah \& Zain, 2010) the use of media in teaching and learning activities is very important especially for the elementary level because at this time the students are still thinking concretely or still unable to think abstractly. Besides, the teachers must be able to actively involve their students in the learning process in the class both individually and in groups. In learning, the students are lack to read well in the class

Besides the use of an appropriate learning model, the use of media must be considered. One of the media that can be used is fairy tales. The use of fairy tales as media in the application of the Cooperative Integrated Reading and Composition (CIRC) learning model will be more optimal and attract students' attention to follow the learning process well. Considering that giving a fairy tale is one of the activities that is liked by children. Fairy tales can also be used to convey a benevolent message to children and will have a positive effect on children's development (Visikoknox-johnson, 2016). Besides being used as a conveyance of a message, fairy tales can be also used as stimuli for creative and critical thinking about the world around (Kulikovskaya \& Andrienko, 2016). According to (Rotmann, 2017), the use of language in a fairy tale also uses simple language so that it will make students feel the situations and events in the story which impacts students' interest to participate in learning. For this reason, fairy tales need to be preserved from children's lives. One of them is by using fairy tales in the learning process. The combination of Cooperative Integrated Reading and Composition (CIRC) learning models assisted by fairy tales can have a good impact on students and can improve students' reading skills.

During this time, the research on the CIRC method and its target fairy tales is still a lot in the students' speaking abilities. Such research has been conducted by (Anindyarini et al., 2019; Malau et al., 2019; Putri et al., 2019) who found that the development of CIRC methods assisted by fairy tales media could improve students' speaking skills. Reading skill is very necessary for students since through reading the students can find various kinds of knowledge contained in books and various mass media (Pujana et al., 2014). For this reason, teachers are expected to be able to choose and implement an innovative learning model and supporting learning media to improve students' language skills, especially in reading skills. Thus, this study aims at analyzing the development of fairytale assisted Cooperative Integrated Reading and Composition (CIRC) learning in elementary schools and analyzing their effects on students' reading skills in elementary schools.

\section{Method}

This research was a quasi-experimental study. The research design of the study was the non-equivalent post-test only control group design. The population in this study was all the fifth-grade students of Elementary School X Cluster in Buleleng District, Buleleng Regency who applied The School-Based Curriculum (KTSP) with 98 students. The random sampling technique was applied in this study. In this study, the individuals in the population had distributed into groups or classes so it was not possible to randomize individuals in the population, but the classes or groups were randomized in the population. Then, the two 
selected classes would be randomized again to determine the experimental group and one class as a control group.

The population must be tested first to determine its equivalence by using the one-way analysis of variance analysis (ANAVA A). Based on the analysis of ANAVA $A$ at a significance level of $5 \%$, the $F_{\text {count }}$ value was 1.55 while the $F_{\text {table }}$ value was 2.70 . Thus, it can be seen that $\mathrm{F}_{\text {count }}<\mathrm{F}_{\text {table, }}$, so $\mathrm{HO}$ is accepted. Considering these results, it can be concluded that the three schools in X Cluster, Buleleng District, Buleleng Regency, which apply KTSP are equivalent. After obtaining the results of the equivalence test calculation, the research sample was determined by random sampling techniques and obtained the fifth grade of Kaliuntu 3 Elementary School with 23 students as an experimental group and the fifth grade of Kaliuntu 2 Elementary School with 18 students as a control group. The experimental group was given a treatment in the form of Cooperative Integrated Reading and Composition (CIRC) learning model assisted by fairy tales, while the control group was taught in conventional learning. The stages of the Cooperative Integrated Reading and Composition $(\mathrm{CIRC})$ learning model assisted by fairy tales can be seen in Table 1.

Table 1. The Stages of a Fairy Tale Assisted Cooperative Integrated Reading and Composition (CIRC) Learning Model

\begin{tabular}{|c|c|c|c|}
\hline No & Stage & Teacher & Students \\
\hline \multirow[t]{2}{*}{1} & Orientation & $\begin{array}{l}\text { a. Conducting an apperception by } \\
\text { asking some questions. }\end{array}$ & $\begin{array}{l}\text { a. Responding to the questions from } \\
\text { teachers based on their } \\
\text { knowledge }\end{array}$ \\
\hline & & $\begin{array}{l}\text { b. Delivering the scope of the } \\
\text { material and learning objectives } \\
\text { to students. }\end{array}$ & $\begin{array}{l}\text { b. Listening to the information } \\
\text { conveyed by the teacher. }\end{array}$ \\
\hline 2 & Organization & $\begin{array}{l}\text { a. Dividing students into groups. } \\
\text { b. Distributing the reading material } \\
\text { to be discussed with students. }\end{array}$ & $\begin{array}{l}\text { a. Gathering with a group member. } \\
\text { b. Reading and observing the } \\
\text { reading material. }\end{array}$ \\
\hline 3 & $\begin{array}{l}\text { Concept } \\
\text { Introduction }\end{array}$ & $\begin{array}{l}\text { Introducing a new concept obtained } \\
\text { from fairy tales and worksheets. }\end{array}$ & $\begin{array}{l}\text { Listening to the information and } \\
\text { discussing the fairy tales and } \\
\text { worksheets within group members. }\end{array}$ \\
\hline 4 & Publication & $\begin{array}{l}\text { Providing some opportunities for } \\
\text { students to deliver the results of } \\
\text { their discussions in front of the } \\
\text { class. }\end{array}$ & $\begin{array}{l}\text { Presenting the results of the } \\
\text { discussion in front of the class. }\end{array}$ \\
\hline 5 & $\begin{array}{l}\text { Strengthening } \\
\text { and Reflection }\end{array}$ & $\begin{array}{l}\text { Giving an appreciation and reflection } \\
\text { on the results and learning process } \\
\text { that has been done }\end{array}$ & $\begin{array}{l}\text { Listening to the teacher's } \\
\text { explanation }\end{array}$ \\
\hline
\end{tabular}

Cooperative Integrated Reading and Composition (CIRC) learning models assisted by fairy tales are not only oriented towards learning outcomes but also in the learning process. In the implementation of Cooperative Integrated Reading and Composition (CIRC) learning models assisted by fairy tales, the teacher must be able to use fairy tales for attracting students' attention so the learning feels fun. The analysis of the Cooperative Integrated Reading and Composition (CIRC) learning model assisted by fairy tales can be seen in Table 2. 
Table 2. The Exploration of teaching material and types of fairy tales assisted Cooperative Integrated Reading and Composition (CIRC) Learning Model

\begin{tabular}{|c|c|c|c|}
\hline $\begin{array}{l}\text { Meet- } \\
\text { ing }\end{array}$ & Material & $\begin{array}{l}\text { Used Fairy } \\
\text { Tale }\end{array}$ & Rational Description \\
\hline 1 & $\begin{array}{l}\text { Content of } \\
\text { Reading Text }\end{array}$ & $\begin{array}{l}\text { A Hawk and } \\
\text { Crow }\end{array}$ & $\begin{array}{l}\text { The fable "A Hawk and Crow" has an interesting story } \\
\text { and can give a good message or advice to students. By } \\
\text { using the fairy tale "A Hawk and Crow" students are } \\
\text { more eager to read, students are interested in knowing } \\
\text { the contents of the reading and understand the } \\
\text { contents of the text because the fairy tale is fun and } \\
\text { interesting so the fairy tale "A Hawk and Crow" is } \\
\text { suitable to be used in the material for the first meeting. }\end{array}$ \\
\hline 2 & $\begin{array}{l}\text { Content of } \\
\text { Reading Text }\end{array}$ & $\begin{array}{l}\text { A Dog and Its } \\
\text { Shadow }\end{array}$ & $\begin{array}{l}\text { The fable "A Dog and Its Shadow" has a message or } \\
\text { advice that we deserve. Also, this fable can attract the } \\
\text { students to read so, it can make the students more } \\
\text { enthusiastic in reading and make it easier for students } \\
\text { to understand the contents of the reading text faster } \\
\text { and at the same time students can take a message } \\
\text { implicates in fairy tales and be able to apply them in } \\
\text { daily life. Thus, the fable "A Dog and Its Shadow" is } \\
\text { also suitable for reading text content material at the } \\
\text { second meeting. }\end{array}$ \\
\hline 3 & $\begin{array}{l}\text { Finding fast } \\
\text { and correct } \\
\text { information }\end{array}$ & $\begin{array}{l}\text { A Stork and A } \\
\text { Dog }\end{array}$ & $\begin{array}{l}\text { The fable "A Stork and a Dog" has an interesting story } \\
\text { element. It is expected that the fable can attract } \\
\text { students' interest in reading as well as make it easier } \\
\text { for students to find out information quickly and precisely } \\
\text { related to the material at the third meeting. }\end{array}$ \\
\hline 4 & Kids' Story & $\begin{array}{l}\text { A Clever } \\
\text { Rooster and } \\
\text { Cunning Fox }\end{array}$ & \multirow{4}{*}{$\begin{array}{l}\text { At the fourth meeting up to the seventh meeting of the } \\
\text { fairytale used included "A Clever Roosters and } \\
\text { Cunning Foxes", "A Frog and Jewel", "A Lamb and } \\
\text { Wolf", and "A Swift Stork". The four fairy tales are } \\
\text { suitable for kids' story material at the fourth to the } \\
\text { seventh meeting because they provide very interesting } \\
\text { story content so that they can foster students' interest } \\
\text { in reading. Also, the material is a kids' story, } \\
\text { remembering fairy tales are included in the kids' story }\end{array}$} \\
\hline 5 & Kids' Story & $\begin{array}{l}\text { A Frog and } \\
\text { Jewel }\end{array}$ & \\
\hline 6 & Kids' Story & $\begin{array}{l}\text { A Lamb and A } \\
\text { Wolf }\end{array}$ & \\
\hline 7 & Kids' Story & A Swift Stork & \\
\hline
\end{tabular}

In this study, the collected data were data of students' reading skills. In collecting the data, a reading skill test was used as an instrument. The objective tests (multiple choice) were given to each individual to collect the reading skills test. The objective tests were used during the post-test and were carried out after learning in the experimental and control groups of 25 questions. The instrument validation applied a validity test with two judges (experts). After testing the instrument, the obtained results were analyzed using item validity test with the number of respondents 55 students obtaining 25 valid test items from 30 questions that were tested, then the reliability test of 25 items that obtained the overall reliability of the test items is 0.751 so it has high reliability. After the reliability test was carried out, it was continued with a different power test with the help of Microsoft Excel 2013 which obtained a different power test result of 0.343 so the test equipment was included in a quite good category, and the difficulty level test was obtained around 0.588 so the test was included in the medium criteria.

In this study, the t-test with the polled variance formula was used to analyze the data. Before testing the hypothesis, the prerequisite analysis tests included the normality of the data distribution and the variance homogeneity test. 


\section{Results and Discussion}

\subsection{Results}

After experimenting, the testing of hypothesis against the reading skills scores data has been obtained. In this study, the results of the descriptive statistical analysis data were used to find out the mean, median, mode, variance, and standard deviation. The results of the analysis descriptive statistical data analysis were presented in Table 3.

Table 3. The Recapitulation of Description of Experimental Group and Control Group Reading Skills Data

\begin{tabular}{lcc}
\hline \multicolumn{1}{c}{ Descriptive statistics } & Experimental Group & Control Group \\
\hline Mean & 19,74 & 14,00 \\
Median & 20,18 & 13,25 \\
Modus & 20,51 & 11,51 \\
Variance & 16,79 & 19,83 \\
Standard deviation & 4,10 & 4,45 \\
\hline
\end{tabular}

Based on the results of the descriptive analysis of students' reading skills in table 3 , it shows that the reading skills of the experimental group data distribution were negative, because of Mo> Md>M (20.51>20.18> 19.74). While the distribution of data in the control group was positive because of $\mathrm{Mo}<\mathrm{Md}<\mathrm{M}(11.51<13.25<11.51)$. From the distribution of reading skills score data in the experimental group and the control group showed that the majority of the experimental group score tended to be high, while the control group tended to be low. If it was converted the average reading skills of the experimental group and the control group with a category on a scale of five, it obtained an average score of reading skills in the experimental group around 19.74 belonged to the highest category. While the average score of students' reading skills in the control group was 14.00 belonged to a medium category.

The data distribution of the normality test was done to find out whether the obtained data were normally distributed or not. If it was normally distributed then, hypothesis testing can be done. The normality test in this study applied the chi-square test $(X \wedge 2)$ with the criteria of normally distributed data if $X^{\wedge} 2$ counts $<X^{\wedge} 2$ table. Based on the data analysis, it can be presented the results of the normality test of the reading skills between the experimental group and the control group in Table 4.

Table 4. The Result of Normality Test between Experimental and Control Group

\begin{tabular}{ccccc}
\hline No & Data Group & $\boldsymbol{X}^{2}$ & $\begin{array}{c}\text { Critical value with a } \\
\text { significance level of 5\% }\end{array}$ & Status \\
\hline 1 & Experimental Post-test & 3,6191 & 7,82 & Normal \\
2 & Control Post-test I & 4,2913 & 7,82 & Normal \\
\hline
\end{tabular}

Based on the results of calculations using the chi-square formula, it was obtained $\mathrm{X} 2_{\text {count }}$ post-test results of the experimental group around 3,6191 and $\mathrm{X} 2$ table a a significance level of $5 \%$ and $\mathrm{dk}=3$ of 7.82 . It meant, $X 2$ count of the experimental group reading skills is smaller than $X 2$ table ( $X 2$ count $<X 2$ table). It meant that the data scores on the reading skills of the experimental group were normally distributed. Whereas in the control group, the results of calculations using the chi-square formula, obtained $\mathrm{X} 2$, the post-test results of the control group were 4.2913 and $X 2$ table at a significance level of $5 \%$ and $\mathrm{dk}=3$ of 7.82 . It meant, X2 count of the control group's reading skills was smaller than X2 table (X2 count $<$ X2 table). This meant that the data for the reading skills of the control group were normally distributed.

Based on assumption testing, it was found that the reading skills of the experimental group and control group students were normally distributed and had a homogeneous variance. After the assumption of test results was obtained, the analysis continued with 
testing the research hypothesis $(\mathrm{Ha})$ and the null hypothesis $(\mathrm{H} 0)$. Hypothesis testing was done using an independent sample t-test (not correlated) with the polled variance formula. The summary of the t-test result analysis can be seen in Table 5 .

Tabel 5. The Summary of T-Test Result

\begin{tabular}{ccccccc}
\hline Group & $\mathbf{n}$ & $\mathbf{D}_{\mathbf{b}}$ & Mean $(\overline{\boldsymbol{x}})$ & $\mathbf{s}^{2}$ & $\mathbf{T}_{\text {count }}$ & $\mathbf{T}_{\text {table }}$ \\
\hline Experimental & 23 & \multirow{2}{*}{39} & 19,74 & 16,79 & \multirow{2}{*}{4,31} & 2,042 \\
Control & 18 & & 14,00 & 19,83 & \\
\hline
\end{tabular}

Based on table 5, it can be seen that the $t_{\text {count }}$ was 4.31 and the table was 2.042 for $\mathrm{db}=39$ at the $5 \%$ significance level. Based on testing criteria, because of $t_{\text {count }}>t_{\text {table }}, H 0$ is rejected and $\mathrm{Ha}$ is accepted.

After testing the hypothesis, the estimated marginal mean score of students' reading skills was calculated. The summary of the estimated marginal score of the experimental group and the control group's reading skills can be seen in Table 6.

Table 6. Estimated Marginal Means

\begin{tabular}{cccccc}
\hline Dependent & \multirow{2}{*}{ Group } & \multirow{2}{*}{ Mean } & \multirow{2}{*}{ Std. Error } & \multicolumn{2}{c}{ 95\% Confidence Interval } \\
\cline { 5 - 6 } & & & Lower Bound & Upper Bound \\
\hline Reading Skill & Experimental & 19,609 & 0,888 & 17,813 & 21,404 \\
& Control & 14,222 & 1,003 & 12,193 & 16,252 \\
\hline
\end{tabular}

Based on the calculation of estimated marginal means using SPPS 20.0, the estimated marginal means in the experimental group was 19,609 while, the control group was 14,222. Thus, the result calculation of the estimated marginal means of the experimental group was greater than the estimated marginal means of the control group.

\subsection{Discussion}

Based on data analysis using t-test, it can be seen that $t_{\text {count }}$ was 4.31 with $t_{\text {table }}$ of 2.042 at a significance level of $5 \%$. The calculation results show that $t_{\text {count }}$ was greater than $t_{\text {table }}$ ( $\left.t_{\text {count }}>t_{\text {table }}\right)$ then $\mathrm{HO}$ was rejected and Ha was accepted. It means that there is a significant difference in students' reading skills between two groups who are taught using Cooperative Integrated Reading and Composition (CIRC) learning models assisted by fairy tales and who are taught using conventional learning.

If it was seen from the estimated marginal means, the average score of reading skills in the experimental group was greater than the average of reading skills in the control group $(19,609>14,222)$. It shows that the reading skills of students who are taught using Cooperative Integrated Reading and Composition (CIRC) learning models assisted by fairy tales are higher than the groups of students who are taught using conventional learning. So, the fairytale-assisted Cooperative Integrated Reading and Composition ( $\mathrm{CIRC}$ ) learning model has a positive effect on students' reading skills.

The findings of the study indicate that the fairy-tale assisted Cooperative Integrated Reading And Composition (CIRC) learning model has a positive effect on students' reading skills, it is caused by several factors. The first factor is, the use of cooperative learning models using Cooperative Integrated Reading and Composition (CIRC) assisted by fairytalecentered learning situations, teachers are as facilitators to make students active in building their knowledge. Also, fairy tales assisted learning can be more meaningful because it provides a more effective way for students to express and illustrate whatever it is in their minds, it also provides information so students who don't know something become know (Shekhawat, Vishakha Deerendra, 2018). This is in line with research conducted by Setiawati et al. (2017) which states that the activities of the CIRC learning model are centered on students' side and teachers are as facilitators. Besides, research conducted by (Sulistiantini et al., 2014) states that the CIRC learning model prioritizes the students' roles and activities in learning and the teacher only acts as a facilitator. 
Second, fairytale assisted Cooperative Integrated Reading and Composition (CIRC) learning provides an opportunity for students to learn reading and writing in an integrated manner of reading. Learning using Cooperative Integrated Reading and Composition (CIRC) learning model assisted by fairytale shows an increase in every students' reading skills. The description is in line with the opinion of Suantini et al. (2013) which states that the CIRC type of cooperative learning model can be categorized as integrated learning. Learning by using CIRC model also provides an opportunity for students to convey their understanding and practice reading skills in pairs and small groups, predict how the story will end, summarize the story, and write the responses proposed by his teacher (Mubarak \& Rudianto, 2017).

The different learning stages between Cooperative Integrated Reading and Composition (CIRC) learning models assisted with fairy tales with conventional learning have a different impact on students' reading skills. Other findings related to the application of fairytale-assisted Cooperative Integrated Reading and Composition (CIRC) learning model are as follows. Looking at the learning process using Cooperative Integrated Reading and Composition (CIRC) learning model assisted by fairy tales, the students are more active in learning activities, students often give some opinions and more enthusiastic to learn. In contrast to the results of initial observations where the students' involvement in the learning process is very limited even just waiting for instruction from the teacher during the learning process. By implementing CIRC learning model, it can also enhance reading comprehension and increase student vocabulary (Jahanbakhsh et al., 2019).

In learning using a fairy tale-assisted Cooperative Integrated Reading and Composition (CIRC) learning model, students are not only responsible for learning themselves, but students also have responsibilities in groups. Through group discussions, the students can express their opinions to solve a particular problem and exchange the information as well develop an attitude of respect and learn to discuss.

Besides, through a group discussion, the students are required to be active, learn together, help each other so they can achieve their goals, or complete the assigned tasks. The students are given the opportunity freely to work together with their groups so the learning activities are more student-centered. It makes the reading skills better to be understood by students so it has a positive impact on students' reading skills. This is in line with the opinion expressed by Mahardika et al. (2017) which states that cooperative learning is creating a learning situation to encourage students to be active and help each other in mastering the material to achieve maximum achievement.

Unlike the case with the control group that uses conventional learning, the teacher dominates more the learning activities. In the learning process, students look passive and only take notes, do assignments based on the teacher's instructions, and listen to the teacher's explanation. These findings are in line with research conducted by Santini et al. (2014) states that in conventional learning, the learning process is teacher-centered so students tend to be passive. Thus, the reading skills of students who are taught using Cooperative Integrated Reading and Composition (CIRC) learning models assisted by fairy tales better than students who are taught using conventional learning. According to Lestari et al. (2017), conventional learning refers to teacher-centered with lecturing, question and answer, and assignment methods.

This study corroborates the research conducted by Sugiartini et al. (2013) shows that there are significant differences in learning outcomes in social studies subjects between students who are taught using Cooperative Integrated Reading and Composition (CIRC) learning models and students who are taught using conventional learning models of the sixth grade of Elementary School I Cluster Manggis District Karangasem Academic Year 2012/2013. Cooperative Integrated Reading and Composition (CIRC) learning model influences students' social studies learning outcomes.

Supported research conducted by Wedayanti et al. (2013) shows that there are significant differences in reading and writing skills between students who are taught using CIRC (Cooperative Integrated Reading and Composition) learning model assisted by picture and students who are taught using conventional learning. The CIRC (Cooperative Integrated 
Reading and Composition) learning model influences the reading and writing skills of fourthgrade students of Elementary School of 18 Pemecutan, Denpasar Utara.

The above description illustrates that this study implies that Cooperative Integrated Reading and Composition (CIRC) learning model assisted by fairy tales has been able to make a positive contribution to improve students' reading skills. Based on the results of the analysis and findings in this study, it can be interpreted that there are significant differences in reading skills between the groups of students who are taught using Cooperative Integrated Reading and Composition (CIRC) learning models assisted by fairy tales and the groups of students who are taught using conventional learning of the fifth-grade students of elementary Cluster X Buleleng District Buleleng Regency 2017/2018 Academic Year. The findings of the study have an impact on increasing students' reading skills. Research on the implementation of Cooperative Integrated Reading and Composition (CIRC) learning models needs to be further developed in the learning process both for Indonesian and other subjects so that students become more active and enthusiastic in learning.

\section{Conclusion and Suggestions}

Based on the results of the study and discussion, it can be concluded as follows. There is a significant difference in reading skills between groups of students who are taught using learning model Cooperative Integrated Reading and Composition (CIRC) assisted by fairy tales and groups of students who are taught using conventional learning of the fifthgrade students of an elementary school in Cluster X Buleleng District, Buleleng Regency 2017/2018 Academic Year. From the post-test score, it can be seen that the average score of the experimental group's reading skills is greater than the control group. It means that the average score of the experimental group reading skills using the Cooperative Integrated Reading and Composition (CIRC) learning model assisted by fairy tales is better than the control groups that are taught using conventional learning. Thus, it can be concluded that Cooperative Integrated Reading and Composition (CIRC) learning model assisted by fairy tales has a significant effect on the reading skills of the fifth-grade students of an elementary school in X Cluster Buleleng District, Buleleng Regency, Academic Year 2017/2018. There are some recommendations as follows; 1 ) It is recommended to elementary school teachers if they find a similar problem with this study. They can use Cooperative Integrated Reading and Composition (CIRC) learning model assisted by fairy tales to improve students' reading skills, 2) It is recommended to elementary school principals to make the results of this study as a reference or guideline in making policy as an effort to improve students' reading skills, and 3) It is recommended to other researchers who are interested in conducting further research on Cooperative Integrated Reading and Composition (CIRC) learning models assisted by fairy tales with similar variables or different variables can use this study as a reference to make a better research.

\section{References}

Ahmadi, M. R. (2017). The impact of motivation on reading comprehension. International Journal of Research in English Education, 2(1), 1-7. https://doi.org/10.18869/acadpub.ijree.2.1.1

Anindyarini, A., Sumarwati, S., Waluyo, B., Hastuti, S., \& Mujiyanto, Y. (2019). Strategi menghidupkan budaya literasi melalui dongeng. Senadimas, September. http://ejurnal.unisri.ac.id/index.php/sndms/article/view/3257/2736

Aziz, Z., \& Hossain, M. A. (2010). A comparison of cooperative learning and conventional teaching on student's achievement in secondary mathematics. Procedia - Social and Behavioral Sciences, 9, 53-62. https://doi.org/10.1016/j.sbspro.2010.12.115

Djamarah, S. B., \& Zain, A. (2010). Strategi Belajar Mengajar. Rineka Cipta.

Durukan, E. (2011). Effects of cooperative integrated reading and composition (CIRC) technique on reading-writing skills. Educational Research and Reviews, 6(1), 102-109. https://academicjournals.org/article/article1379666882_Durukan.pdf

Ilham, M. J., Hasanah, M., \& Pratiwi, Y. (2016). Integrated reading and composition ( CIRC ) bermuatan nilai karakter terhadap kemampuan menulis cerpen siswa kelas VII. Jurnal 
Pendidikan

Humaniora,

$4(3)$,

$121-131$.

http://journal.um.ac.id/index.php/jph/article/view/8215

Ismail, H., Syahruzah, J. K., \& Basuki, B. (2017). Improving the students' reading skill through translation method. Journal of English Education, 2(2), 124-131. https://doi.org/10.31327/jee.v2i2.405

Jahanbakhsh, A. A., AliAsgariZamani, M., \& Garman, Z. (2019). CIRC and STAD in Iranian context: through the five elements to cooperative learning of lexical collocations. Cogent Arts and Humanities, 6(1). https://doi.org/10.1080/23311983.2019.1692469

Kartika, C. I., Partadjaya, T. R., \& Widiana, I. W. (2013). Pengaruh model pembelajaran CIRC berbasis jolly phonics terhadap kemampuan membaca dan menulis siswa kelas II SD gugus II kecamatan Sukawati. Mimbar PGSD Universitas Pendidikan Ganesha, 2(2). https://doi.org/http://dx.doi.org/10.23887/jjpgsd.v1i1.1397

Khoirunisa, E., Gunarhadi, G., Choiri, A. S., \& Sunardi, S. (2017). The use cooperative integrated reading and composition (CIRC) method to improve reading comprehension ability of visualy impaired students in the 3rd grade of SD SLB A YKAB Surakarta, Indonesia. European Journal of Special Education Research, 2(1), 59-70. https://doi.org/10.5281/zenodo.224515

Kulikovskaya, I. E., \& Andrienko, A. A. (2016). Fairy-tales for modern gifted preschoolers: developing creativity, moral values and coherent world outlook. Procedia - Social and Behavioral Sciences, 233(May), 53-57. https://doi.org/10.1016/j.sbspro.2016.10.129

Kurniasih, I., \& Sani, B. (2016). Ragam Pengembangan Model Pembelajaran. Kata Pena.

Lestari, N. K. T., Kristiantari, M. R., \& Ganing, N. N. (2017). Pengaruh model pembelajaran talking stick berbantuan lagu daerah terhadap hasil belajar IPS. International Journal of Elementary Education, 1(4), 290-297. https://doi.org/http://dx.doi.org/10.23887/ijee.v1i4.12960

Loberg, O., Hautala, J., Hämäläinen, J. A., \& Leppänen, P. H. T. (2019). Influence of reading skill and word length on fixation-related brain activity in school-aged children during natural reading. Vision Research, 165(February), 109-122. https://doi.org/10.1016/j.visres.2019.07.008

Mahardika, I. M. A. Y., Agung, A. A. G., \& Rendra, N. T. (2017). Pengaruh model pembelajaran scramble terhadap hasil belajar bahasa Indonesia siswa kelas III. EJournal PGSD Universitas Pendidikan Ganesha, 5(2), 1-11. https://doi.org/http://dx.doi.org/10.23887/jjpgsd.v5i2.10888

Malau, D. C., Permata, E. L., Rahmaniyar, F., Meilani, L., Nurjanah, L., \& Husna, M. (2019). Penerapan metode dongeng dan cerita serial fabel untuk meningkatkan kemampuan membaca permulaan. Proceedings Humanis Universitas Pamulang, 1(2). http://openjournal.unpam.ac.id/index.php/Proceedings/article/view/4104

Maulida, A., Sudarma, I. K., \& Japa, I. G. N. (2017). Pengaruh model pembelajaran value clarification technique bermediakan video terhadap hasil belajar Pkn. Mimbar PGSD Universitas Pendidikan Ganesha, https://doi.org/http://dx.doi.org/10.23887/jjpgsd.v5i2.11003

Motaei, B. (2014). On the effect of cooperative learning on general English achievement of Kermanshah Islamic Azad University students. Procedia - Social and Behavioral Sciences, 98, 1249-1254. https://doi.org/10.1016/j.sbspro.2014.03.540

Mubarak, Z. H., \& Rudianto, G. (2017). Cooperative integrated reading and composition (CIRC) technique in writing subject of EFL context. Advances in Social Science, Education and Humanities Research (ASSEHR), 148. https://doi.org/https://dx.doi.org/10.2991/icla-17.2018.8

Pfost, M., Blatter, K., Artelt, C., Stanat, P., \& Schneider, W. (2019). Effects of training phonological awareness on children's reading skills. Journal of Applied Developmental Psychology, 65. https://doi.org/10.1016/j.appdev.2019.101067

Pujana, I. B. W. A., Arini, N. W., \& Sudatha, I. G. W. (2014). Pengaruh metode pembelajaran SQ3R terhadap hasil belajar bahasa Indonesia kelas V SD. Jurnal Mimbar PGSD Universitas Pendidikan Ganesha, 2(1).

Putri, P. N. A. K., Arini, N. W., \& Sumantri, M. (2019). Pengaruh strategi directed reading 
thinking activiy (DRTA) berbantuan media flip chart terhadap keterampilan membaca pemahaman. Jurnal Ilmiah Sekolah Dasar, 3(2), 158-166. https://doi.org/http://dx.doi.org/10.23887/jisd.v3i2.17762

Ristanto, R. H., Zubaidah, S., Amin, M., \& Rohman, F. (2017). the potential of cooperative integrated reading and composition in Biology learning at higher education. International Journal of Educational Research Review. https://doi.org/10.24331/ijere.376727

Rotmann, S. (2017). "Once upon a time..." Eliciting energy and behaviour change stories using a fairy tale story spine. Energy Research and Social Science, 31(November 2016), 303-310. https://doi.org/10.1016/j.erss.2017.06.033

Sandiyani, L., Kusmariyatni, N., \& Dibia, I. K. (2016). Pengaruh model pembelajaran CIRC (cooperative integrated reading and composition) berbantuan cerita pendek terhadap keterampilan membaca pemahaman. Mimbar PGSD Universitas Pendidikan Ganesha, 4(1). https://doi.org/http://dx.doi.org/10.23887/jjpgsd.v4i2.7640

Santini, I. A. N. S., Putra, I. K. A., \& Negara, I. G. A. O. (2014). Penagruh pembelajaran kooperatif CIRC berbantuan media visual terhadap keterampilan membaca pada bahasa Indonesia siswa kelas IV SD gugus II Tampaksiring. Mimbar PGSD Universitas Pendidikan Ganesha, 2(1). https://doi.org/http://dx.doi.org/10.23887/jjpgsd.v2i1.1922

Setiawati, N. P. Y., Arini, N. W., \& Suarni, N. K. (2017). Pengaruh model pembelajaran CIRC berbasis tulisan eksposisi terhadap kemampuan membaca intensif siswa kelas IV. Mimbar PGSD Universitas Pendidikan Ganesha, 5(2). https://doi.org/http://dx.doi.org/10.23887/jjpgsd.v5i2.11017

Shekhawat, Vishakha Deerendra, P. M. (2018). Impact of fairy tales on the development of imagination level of preschool children. Journal of Advances and Scholarly Researches in Allied Education.

Suantini, N. L. P. Y., Jampel, I. N., \& Widiana, I. W. (2013). Pengaruh model pembelajaran kooperatif tipe CIRC terhadap pemahaman konsep IPA siswa kelas IV di gugus II kecamatan Gerokgak. Mimbar PGSD Universitas Pendidikan Ganesha, 1(1). https://doi.org/http://dx.doi.org/10.23887/jjpgsd.v1i1.739

Sugiartini, N. K. R., Antari, N. N. M., \& Suartama, I. K. (2013). Pengaruh model pembelajaran cooperative integrated reading and composition (CIRC) terhadap hasil belajar IPS kelas IV gugus I kecamatan Manggis. Mimbar PGSD Universitas Pendidikan Ganesha, 1(1). https://doi.org/http://dx.doi.org/10.23887/jjpgsd.v1i1.699

Sulistiantini, N. M. P., Dibia, I. K., \& Widiana, I. W. (2014). Pengaruh CIRC terhadap keterampilan membaca pemahaman siswa kelas V gugus XI kec. Buleleng tahun 2013. Mimbar PGSD Universitas Pendidikan Ganesha, 2(1). https://ejournal.undiksha.ac.id/index.php/JJPGSD/article/download/4142/3262

Sumantri, M., Sudana, D. N., \& Yoni, P. I. B. E. (2017). Penerapan media gambar dan kartu huruf untuk meningkatkan keterampilan membaca permulaan. International Journal of Elementary Education, $1, \quad 1-10$. https://doi.org/http://dx.doi.org/10.23887/ijee.v1i1.11433

Visikoknox-johnson, L. (2016). The positive impacts of fairy tales for children. Hohonu, 14. https://hilo.hawaii.edu/campuscenter/hohonu/volumes/documents/ThePositivelmpactsof FairyTalesforChildrenLeilaniVisikoKnox-Johnson.pdf

Wedayanti, N. W. A., Putra, I. K. A., \& Meter, I. G. (2013). Pengaruh model pembelajaran CIRC berbantuan gambar berseri terhadap keterampilan membaca dan menulis siswa kelas IV SDN 18 Pemecutan. Mimbar PGSD Universitas Pendidikan Ganesha. https://ejournal.undiksha.ac.id/index.php/JJPGSD/article/download/965/835

Yudasmini, N. M., Marhaeni, A. A. I. N., \& Jampel, N. (2015). Pengaruh model pembelajaran CIRC (cooperative integrated reading and composition) terhadap minat baca dan kemampuan memahami bacaan pada siswa kelas VI di sekolah dasar gugus Buruan. E-Journal Program Pascasarjana Universitas Pendidikan Ganesha Program Studi Penelitian Dan Evaluasi Pendidikan, 5(1). https://doi.org/10.5194/acpd-9-26265-2009 